https://doi.org/10.52058/2708-7530-2021-4(10)-148-162

Обушна Наталія Іванівна доктор наук з державного управління, доцент, професор кафедри публічного управління та публічної служби, Національна академія державного управління при Президентові України, вул. Антона Цедіка, 20, м. Київ, 03057, тел.: (068) 252-40-53, e-mail: n25obushna@gmail.com, https://orcid.org/0000-0001-5612-3104

Петринська Вікторія Валеріївна магістр публічного управління та адміністрування; головний спеціаліст відділу розвитку культури та мистецтва управління культури i туризму Кропивницької міської ради, вул. Кропивницького, буд.7, корп.1, кв. 24, м. Кропивницький, 25006, тел.: (050) 53762-33, e-mail: vikylinka1987@ukr.net, https://orcid.org/0000-0002-8544-9848

\title{
МОДЕРНІЗАЦІЯ ДЕРЖАВНОЇ СЛУЖБИ ТА УПРАВЛІННЯ ЛЮДСЬКИМИ РЕСУРСАМИ В УКРАЇНІ: ОБ'ЄКТИВНА НЕОБХІДНІСТЬ ТА ОСОБЛИВОСТІ РЕАЛІЗАЦІї
}

Анотація. У статті обгрунтовано необхідність модернізації державної служби та управління людськими ресурсами в Україні. Уточнено сутність базових дефініцій дослідження, серед яких “модернізація”, “державна служба”, “людські ресурси" та "HR-менеджмент". На підставі проведеного аналізу виявлено основні проблеми функціонування вітчизняної державної служби та управління людськими ресурсами. 3 огляду на це, обгрунтовано, що державна служба України потребує цільової переорієнтації всього комплексу інституційного дизайну системи для забезпечення ii дієздатності, ефективності, професійності, відкритості та прозорості в контексті формування сервісно-орієнтованої культури державного управління загалом. При цьому серед пріоритетів модернізації державної служби та управління людськими ресурсами визначено такі: розвиток законодавства у сфері державної служби з урахуванням принципів SIGMA; оптимізація системи центральних органів виконавчої влади та посилення інституційної спроможності Національного агентства України з питань державної служби; упровадження сучасної практики відбору персоналу на основі заслуг; запровадження прозорої та справедливої системи оплати праці на основі класифікації посад; розгортання HRMIS; запровадження інноваційних підходів до професійного розвитку державних службовців; формування єдиної бази даних 
кадрового резерву; трансформація організаційної культури державної служби в контексті сервісно-орієнтованого розвитку та ін. Зроблено висновок, що успіх модернізації державної служби та управління людськими ресурсами значною мірою залежить від переосмислення традиційних HR-підходів до роботи 3 персоналом у державних органах, пошуку й закріплення інноваційних HRпрактик (у т.ч. й цифрових), які б враховували потреби державних службовців та створювали умови для їх постійного самовдосконалення, самопізнання й самореалізації в умовах нових викликів.

Ключові слова: державне управління, державна служба, людські ресурси, модернізація, HR менеджмент, цифровий HR.

Obushna Nataliia I. Doctor of Science in Public Administration, Associate Professor, Professor of the Department of Public Administration and Public Service, National Academy for Public Administration under the President of Ukraine, A. Tsedik St., Kyiv, 03057, tel.: (068) 252-40-53, e-mail: n25obushna@gmail.com, https://orcid.org/0000-0001-5612-3104

Petrynska Viktoriia V. Master of Public Administration; Chief Specialist of of the Department of Culture and Tourism of Kropyvnytskyi City Council, Kropyvnytska St., 7, Kropyvnytskyi, 25006, tel.: (050) 537-62-33, e-mail: vikylinka1987@ukr.net, https://orcid.org/0000-0002-8544-9848

\title{
MODERNIZATION OF CIVIL SERVICE AND HUMAN RESOURCES MANAGEMENT IN UKRAINE: OBJECTIVE NEED AND FEATURES OF IMPLEMENTATION
}

\begin{abstract}
The article substantiates the need to modernize the civil service and human resources management in Ukraine. The essence of the basic definitions of the study, including "modernization", "civil service", "human resources" and "HRmanagement". Based on the analysis, the main problems of the functioning of the domestic civil service and human resources management were identified. Given this, it is justified that the civil service of Ukraine needs a targeted reorientation of the whole complex of institutional design of the system to ensure its efficiency, effectiveness, professionalism, openness and transparency in the context of forming a service-oriented culture of public administration in general. At the same time, among the priorities of civil service modernization and human resources management are the following: development of legislation in the field of civil service taking into account the principles of SIGMA; optimization of the system of central executive bodies and strengthening the institutional capacity of the National Agency of Ukraine for Civil Service; introduction
\end{abstract}


of modern and effective merit-based recruitment practices; introduction of a transparent and fair remuneration system based on job classification; deployment of HRMIS; introduction of innovative approaches to professional development of civil servants; formation of a single database of personnel reserve; transformation of the organizational culture of the civil service in the context of service-oriented development, etc. It is concluded that the success of civil service modernization and human resource management largely depends on rethinking traditional HR approaches to working with staff in government agencies, finding and consolidating innovative HR practices (including digital) that would take into account the needs civil servants and created conditions for their constant self-improvement, self-knowledge and self-realization in the face of new challenges.

Keywords: public administration, civil service, human resources, modernization, HR management, digital HR.

Постановка проблеми. На сьогодні в системі державного управління України активно здійснюються кардинальні реформи ${ }^{2}$, успіх реалізації яких, у першу чергу, критично залежать від можливості “створення спроможної, стійкої, професійної та незалежної вітчизняної державної служби, сучасних процедур для ухвалення й виконання ефективних рішень, іміджу державної служби як конкурентного роботодавця, привабливого для мотивованих i компетентних фахівців...[1, с. 24]”. I це є логічним, адже нові вимоги до державного управління висувають відповідні вимоги до державної служби та іiі головного ресурсу державних службовців, здатних надавати якісні послуги та працювати на досягнення результатів в інтересах суспільства, застосовувати європейські стандарти державного управління та виробляти державну політику в умовах змін.

При цьому А. Колодій слушно зауважує, що “на попередніх етапах розвитку України протягом років незалежності до неуспіху призвела трансформація без модернізації, половинчастість замін та викривлення змін...Тож, враховуючи власний негативний досвід, маємо тепер не випустити з-під уваги необхідність доведення до кінця необхідних замін i трансформацій, i продовження та закріплення їх реформами, спрямованими на модернізацію” [2]. Таке бачення суспільно-політичних трансформацій загалом прекрасно пояснює доцільність використання модернізаційного підходу, який може перетворитися в інструмент пізнання та пояснення нових шляхів розвитку, поліпшення й удосконалення соціальних інститутів, суспільних відносин та ін.

Отже, можемо констатувати, що в умовах переходу “від державного адміністрування до державного менеджменту, від бюрократичної організації до

\footnotetext{
2 Згідно прийнятої в 2016 р. Стратегії реформування державного управління, що була оновлена в кінці 2018 р. на основі рекомендацій, сформульованих Програмою SIGMA/OECD.
} 
сервісної держави” [3, с. 11] питання комплексної модернізації державної служби та управління людськими ресурсами (HR - human resources (людські ресурси)) як ключового драйвера успішного реформування системи державного управління набувають особливої актуальної та науково-практичної значущості.

Аналіз останніх досліджень і публікацій. Студіювання наукових праць засвідчує, що проблематиці модернізації державної служби та управління людськими ресурсами у світовій і вітчизняній державно-управлінській практиці та споріднених науках (економіка, соціологія, психологія, політологія, право) присвячено численні публікації. Зокрема, досить грунтовно ця проблематика розроблена в працях таких зарубіжних і вітчизняних учених, як: В. Авер'янова, Г. Атаманчука, В. Бакуменка, Г. Беккера, Р. Войтович, Н. Гончарук, С. Зелінського, О. Линдюк, Л. Прудиус, С. Селіванова, С. Серьогіна, та ін.

Незважаючи на досить вагомі напрацювання науковців за вказаним напрямом, фундаментальні наукові розробки щодо вищеозначеної проблематики в умовах утвердження антропологічної спрямованості державного управління ще залишаються далекими від завершення, тому перебувають в епіцентрі серйозних наукових дискусій.

Мета статті. 3 огляду на зазначене, головна ідея статті полягає в обгрунтуванні об’єктивної необхідності та особливостей модернізації державної служби та управління людськими ресурсами (HR) як ключового драйвера успішного реформування системи державного управління в Україні.

Виклад основного матеріалу. Слідуючи настановам відомого філософа Р. Декарта, якому належить афоризм "Уточніть значення слова, $i$ ви позбавите світ від половини непорозумінь та помилок” [4], вважаємо за доцільне, розпочати із узгодження сутності базових понять даної статті.

Етимологічно термін “модернізація” пов’язаний із французькими moderne сучасний, новітній та modernisation, що означає оновлення, а також 3 англійським однокореневими термінами modern, modernity, modernization, щодо яких можливі два варіанти перекладу на українську мову [5, с. 218]: 1) буквальний: коли всі терміни перекладаються спорідненими словами: модерн, модерний і модернізація; 2) український варіант: сучасний, сучасність та осучаснення.

Найчастіше під модернізацією будь-якого об’єкта розуміють процес його оновлення або ж осучаснення. Однак, ототожнення категорій "модернізаціі” та “осучаснення" є не зовсім коректним, адже методологічно вони не збігаються між собою. У зв’ язку з цим Р. Войтович [6, с. 16] також констатує, що “осучаснення $\epsilon$ складовою модернізації, оскільки воно передбачає наявність певного еталона сучасності, зіставлення з яким породжує прагнення досягти або зрівнятися 3 вищим рівнем”.

На наше переконання, при дослідженні процесу модернізації необхідно 
виходити 3 різних його аспектів, з визначення внутрішніх цілей яких фактично формується зміст державного управління та залежить його здатність інтегрувалися в сучасну управлінську концепцію належного урядування (Good Governance). Відповідно в межах даного дослідження модернізація розглядається нами як системний процес різного роду зрушень і перетворень у сфері державної служби та управління людськими ресурсами в напрямі їх оновлення й постійного якісного вдосконалення.

Легальне визначення поняття “державна служба" знаходимо в статті 1 Закону України "Про державну службу” [7, ст. 1], яка закріплює, що державна служба в Україні - це публічна, професійна, політично неупереджена діяльність із практичного виконання завдань і функцій держави, зокрема щодо: 1) аналізу державної політики на загальнодержавному, галузевому і регіональному рівнях та підготовки пропозицій стосовно їі формування, у т. ч. розроблення та проведення експертизи проектів програм, концепцій, стратегій, проектів законів та ін. нормативно-правових актів, проектів міжнародних договорів; 2) забезпечення реалізації державної політики, виконання загальнодержавних, галузевих i регіональних програм, виконання законів та інших нормативно-правових актів; 3) забезпечення надання доступних і якісних адміністративних послуг; здійснення державного нагляду та контролю за дотриманням законодавства; управління державними фінансовими ресурсами, майном та контролю за їх використанням; управління персоналом державних органів; 7) реалізації ін. повноважень державного органу, визначених законодавством.

Отже, державна служба полягає у виконанні державними службовцями завдань і функцій держави, що реалізуються через відповідні державні органи.

Водночас доцільно нагадати, що з моменту прийняття незалежності України, коли було започатковано наздоганяючи модернізацію, i до сьогодні в державі відбулися грунтовні зміни, пов'язані 3 реформування системи державного управління в напрямку впровадження засад демократичного врядування, що грунтується на принципах верховенства права. Проте, саме за роки незалежності в Україні особливо помітно проявилися найбільш негативні тенденції на державній службі, що обумовлені певною невідповідністю результатів іiі функціонування сучасним потребам і вимогам суспільства у проведенні комплексних реформ у різних сферах державної політики, а також європейським стандартам належного урядування. Підтвердженням означеної проблемної ситуації є надзвичайно низькі позиції України у світових рейтингах конкурентоспроможності (У т.ч. й пов'язаних із державним управлінням). Так, за Індексом глобальної конкурентоспроможності 2019-2020 (The Global Competitiveness Index) Україна посіла 85-е місце серед 140 країн світу (відкотилися до показника трирічної давнини) [8]. При цьому досить катастрофічно виглядають позиції України серед 
інших країн світу по категорії “Державні і суспільні установи”, зокрема в таких позиціях, як “Право власності”, “Етика і корупція”, “Зловживання впливом” та "Безпека".

За результатами глобального Індексу сприйняття корупції Transparency International, який агрегує отримані 3 різних джерел відомості про сприйняття рівня корупції у державному секторі різних країн з боку ділових кіл та експертів відповідних країн, Україна отримали у 2020 році лише 117 місце зі 180 країн у списку CPI (Corruption Perceptions Index - CPI) [9].

На нашу думку, такі негативні тенденції сформувалися на фоні загального погіршення соціально-економічної ситуації в країні, росту корупції серед державних службовців, політичної нестабільності в країні (анексія частини територій та воєнні дії на Сході країни) та значно ускладнилися в результаті стрімкого поширення на території України гострої респіраторної хвороби COVID19, спричиненої коронавірусом SARS-CoV-2 (далі - COVID-19), і запровадження відповідних карантинних заходів. Звідси є очевидним, що державна служба України потребує “цільової переорієнтації всього комплексу інституційного дизайну системи для забезпечення дієздатності, ефективності, професійності, відкритості та прозорості державних інститутів України" [10, с. 138] в контексті формування сервісно-орієнтованої культури державного управління загалом.

При цьому повноцінна модернізація державної служби не може бути реалізована без удосконалення управління людськими ресурсами, так як професійність державної служби забезпечується належними управлінськими стандартами і методами управління людськими ресурсами.

На думку Н. Гончарук та Л. Прудиус, термін “людські ресурси” характеризує 3 якісної, змістовної сторони кадровий склад або весь персонал державного органу і включає здатність до творчості й потенційні можливості всебічного розвитку державних службовців, організаційну культуру, етику i моральну надійність, удосконалення взаємовідносин у колективі, відповідальність, мотивацію та стимулювання тощо [11, с. 44]. У зв’язку з цим, вважаємо за доцільне, більш детально проаналізувати сучасний стан кадрового забезпечення державної служби України.

За інформацією Національного агентства України з питань державної служби (НАДС), на 01.01.2021 року фактична чисельність державних службовців в Україні складала 176527 чол., що на 16481 осіб (або на 8,05\%) менше аналогічного показника на 01.01.2020 року [12]. По відношенню до показника на 01.01.2017 року зменшення фактичної чисельності службовців становило 58209 осіб (або 27,8\%), що відображає організаційні зміни та тенденції змін посад у державних структурах України (табл. 1). 


\section{Динаміка загальної чисельності державних службовців}

в Україні протягом 2016-2020 років (на кін. року)*

\begin{tabular}{|c|c|c|c|c|c|}
\hline Роки & $\begin{array}{c}\text { Чисельність } \\
\text { населення, } \\
\text { млн. чол. }\end{array}$ & $\begin{array}{c}\text { Кількість } \\
\text { посад за } \\
\text { штатним } \\
\text { розисом, осіб }\end{array}$ & $\begin{array}{c}\text { Фактична } \\
\text { чисельність } \\
\text { державних } \\
\text { службовців, осіб }\end{array}$ & $\begin{array}{c}\text { Темп приросту } \\
\text { фактичної } \\
\text { чисельності держ. } \\
\text { службовців, \% }\end{array}$ & $\begin{array}{c}\text { Чисельність } \\
\text { громадян на 1-го } \\
\text { державного } \\
\text { службовця, осіб }\end{array}$ \\
\hline 2016 & 42,59 & 268378 & 234736 & $-12,5$ & 181 \\
\hline 2017 & 42,39 & 242028 & 207252 & $-11,7$ & 205 \\
\hline 2018 & 42,22 & 244605 & 209785 & 1,22 & 201 \\
\hline 2019 & 41,90 & 253553 & 193008 & $-8,00$ & 217 \\
\hline 2020 & 41,59 & 219844 & 176527 & $-8,05$ & 235 \\
\hline
\end{tabular}

*Джерело: складено на основі [12 (річні звіти НАДС за 2017-2020 рр.); 13]

Згідно публічного звіту Голови НАДС за підсумками діяльності у 2020 рік, фактична чисельність працюючих державних службовців за категоріями посад на поч. 01.01.2021 року становила: кількість осіб категорії "А" - 180, категорії "Б” 43014 та категорії "В” - 133333 особи [12].

Як відомо, зниження кількості державних службовців є одним із основних завдань реформи у сфері державної служби [14]. На думку міжнародних експертів програми SIGMA, скорочення загальної чисельності працівників центральних органів виконавчої влади (ЦОВВ) України щороку не менш як на 2,5 \% кадрового складу таких органів має сприяти підвищенню ефективності державного управління (крім функцій та посад, які може бути передано з ЦОВВ до органів місцевого самоврядування та/або інших державних органів).

При цьому реформа державної служби передбачає поступове оновлення складу міністерств, поетапне реформування інших ЦОВВ та їх територіальних органів (2019-2021 роки) і місцевих держадміністрацій (2020-2021 роки), а також утворення команд фахівців з питань реформ (ФПР) в Офісі Президента України, Секретаріаті Кабінету Міністрів України, міністерствах та інших центральних органах виконавчої влади [14]. У результаті на поч. 2021 року створено понад 80 директоратів в ЦОВВ та прийнято на роботу понад 890 висококваліфікованих державних службовців (з них 62 - генеральні директори, 23 - заступники генеральних директорів, 217 - керівники експертних груп, 588 - державні експерти) [15].

Принципово для державної служби залишається питання гендерного балансу. Загальновідомо, що вітчизняна державна служба має “жіноче обличчя", адже 75,9\% зайнятих на ній - це жінки, частка яких постійно зростає. Проте, є певні диспропорції в залежності від категорії. Наприклад, якщо говорити про категорію “A”, то на поч. 2021 року тут жінок було лише 33,3\% (60 осіб), відповідно 
чоловіків - 66,7\% (120 осіб); у категорії “Б” жінок - 68,6\% (29 518 осіб), а чоловіків - 31,4\% (13 496 осіб); категорію “В” взагалі представляють переважно жінки - 78,3\% (104 404 осіб), а чоловіки лише 21,7\% (28 929 осіб) [12]. Тобто чоловіки, як правило, мають більш високі категорії посад.

Водночас надзвичайно важливою проблемою постає висока плинність кадрів (більше 21\%) у сфері державної служби. У результаті, як влучно відмічає Л. Придиус [16, с. 207], на це витрачається інституційна пам'ять, що не сприяє результативності, ефективності та дієвості функціонування державної служби.

У даному контексті доцільно згадати, що в умовах поширення гострої респіративної хвороби COVID-19 в Україні звичні робочі процеси на державній службі зазнали вагомих змін, так як їх значна частина дуже швидко була переведена в онлайн. Вказані зміни торкнулися й добору на державну службу: у результаті було змінено конкурсну процедура відбору, яка дозволяла проводити конкурсні процедури в умовах соціального дистанціювання.

Так, для забезпечення ефективного функціонування органів державної влади Постановою Кабінету Міністрів України (КМУ) від 22 квітня 2020 року № 290 “Деякі питання призначення на посади державної служби на період дії карантину, установленого з метою запобігання поширенню на території України гострої респіраторної хвороби COVID-19, спричиненої коронавірусом SARS-CoV-2” [17], запроваджено спрощену процедуру добору на зайняття вакантних посад державної служби на період встановлення карантину. Призначення на такі посади здійснювалося шляхом проведення співбесіди 3 визначеними суб'єктом призначення або керівником державної служби у державному органі посадовими особами. Тобто вся відповідальність та повноваження щодо прийняття рішення покладалася на одну особу. На нашу думку, така ситуація повністю паралізувала можливість об’єктивного добору талановитих працівників на державну службу.

Проте, вже в лютому 2021 року Верховна Рада України ухвалила Закон України № 1285-IX “Про внесення змін до деяких законів України щодо відновлення проведення конкурсів на зайняття посад державної служби та інших питань державної служби" [18], який відновлює процедуру проведення конкурсів на зайняття посад державної служби всіх категорій. При цьому протягом шести місяців 3 дня набрання чинності цим документом також необхідно оголосити конкурси на посади, що обіймають особи, з якими раніше були укладені контракти про проходження державної служби на період дії карантину через поширення COVID-19.

Разом із тим зауважимо, що якісне кадрове забезпечення органів державної влади безпосередньо пов'язано з професіоналізацією державної служби. На сьогодні є очевидним, що професійно-кваліфікаційне зростання держслужбовців полягає, насамперед, в їх професійному навчанні, підготовці, перепідготовці та 
підвищенні кваліфікації, які спрямовані на розвиток та збагачення необхідних компетенцій. Проте, на практиці багато питань виникає до механізмів оцінки наявних корпоративних, менеджерських та професійних компетенцій державного службовця, які необхідні для ефективного виконання службових повноважень. Зокрема, законодавством України передбачена процедура проведення оцінювання результатів службової діяльності державних службовців із визначенням компетенцій, рівень яких необхідно підвищити (Постанова КМУ “Про затвердження Порядку проведення оцінювання результатів службової діяльності державних службовців” № 640 від 23.08.2017) [19]. Однак, дана процедура має ряд недоліків, які нівелюють цінність та ефективність такого оцінювання, а найголовніше його результати не мають жодного прикладного значення для розвитку потенційно талановитого працівника та не можуть бути використанні під час побудови плану його професійного зростання.

Ще одним суттєвим недоліком є низький рівень привабливості державної служби для потенційних кандидатів. Адже сьогодні державна служба не може запропонувати, ані конкурентоспроможний рівень заробітної плати чи соціальний пакет, ані гнучкий графік роботи, ані, як правило, баланс між приватним життям та роботою, що, з огляду на теорію поколінь, є одним з визначальних факторів для пошуку роботи кандидатів покоління меленіалів, які до 2025 року будуть представляти більшу частину кандидатів на ринку праці.

Дійсно рівень фінансової мотивації державних службовців в Україні залишається недостатньо привабливим на ринку праці. Хоча, протягом 2016-2020 років у державному секторі середньомісячна заробітна плата демонструє тенденцію до зростання 35953 грн/ос. у 2016 році до 15123 грн/ос. у 2020 році [13]. Загальне зростання середньої заробітної плати за досліджуваний період становить 9170 грн. (або 154\%).

Окрім того, вагомим демотивуючим фактором, який порушує загальний принцип справедливості оплати праці у сфері державної служби, є наявність великих диспропорцій (рівнів компресії - співвідношення між найнижчим та найвищим рівнями оплати) в індивідуальних розмірах оплати праці для посад, які залежать більшою мірою не від результатів діяльності працівників, а від загального фонду оплати праці (ФОП) відомства (наприклад, наявності “економії ФОП”). Для врегулювання проблем пов’язаних з оплатою праці у сфері державної служби у травні 2020 року розпорядженням КМУ № 622-р затверджено Концепцію реформування системи оплати праці державних службовців та план заходів з їі реалізації [20].

Підсумовуючи вищевикладене, можемо констатувати, що основними проблемами функціонування державної служби та управління людськими ресурсами на державній службі в Україні на сьогодні залишаються: 
- відсутність точного моніторингу кількісного складу кадрового забезпечення державної служби, а саме відсутність повноцінної автоматизованої інформаційної системи, яка б дала змогу мати оперативні статистичні дані про стан управління людськими ресурсами;

- високий рівень плинності кадрів;

- гендерний дисбаланс;

- низький рівень мотивації та відповідальності за результати своєї діяльності серед державних службовців;

- недосконала існуюча конкурсна процедура відбору на посади державної служби (у т.ч. й через відсутність кадрового резерву);

- відсутність цілісної системи розвитку професійної компетентності державно-управлінських кадрів;

- низька конкурентність оплати праці (насамперед, для вищого керівництва державної служби) порівняно з приватним сектором;

- наявність великих диспропорцій (рівнів компресії) в індивідуальних розмірах оплати праці для посад (у т.ч. й для посад з подібним функціоналом), які залежать більшою мірою не від результатів діяльності, а від загального ФОП відомства;

- нерозвинена система соціального захисту працівників;

- високий рівень корупції та надмірна політизація кадрової політики в органах державної влади; та ін.

Оскільки більшість ЦОВВ не застосовують сучасні інструменти управління людськими ресурсами та професійного навчання - відсутній достатній рівень професійних знань у сфері добору персоналу на посади державної служби. Окрім того, залишається актуальним питання вдосконалення системи класифікації посад, можливості кар'єрного зростання державних службовців та ін.

Отже, з огляду на викладене, модернізація державної служби та управління людськими ресурсами постає об'єктивною пріоритетною потребою в умовах реформування системи державного управління в Україні загалом.

Нижче окреслимо наше бачення щодо пріоритетів модернізації державної служби та управління людськими ресурсами, які все більше переміщуються в антропологічну площину. Серед них:

- удосконалення та розвиток законодавства у сфері державної служби, зокрема упровадження необхідних змін до Закону України "Про державну службу" на основі принципів SIGMA;

- оптимізація системи ЦОВВ та посилення інституційної спроможності НАДС;

- упровадження сучасної та ефективної практики відбору персоналу на основі заслуг, особливо для державних службовців вищого рівня; 
- запровадження прозорої та справедливої системи оплати праці на основі класифікації посад;

- розгортання інформаційної системи управління людськими ресурсами (HRMIS) в органах виконавчої влади для створення умов відкритого, прозорого та ефективного державного управління;

- запровадження нових підходів до професійного розвитку державних службовців;

- формування єдиної бази даних кадрового резерву, доступної для всіх ЦОВВ;

- трансформація організаційної культури державної служби в контексті сервісно-орієнтованого розвитку та ін.

Вищеокреслені пріоритети в котрий раз підтверджують доцільність осмислення прогресивних тенденцій модернізації державної служби та управління ii людськими ресурсами (HR - human resources (людські ресурси)) безпосередньо через формування нової системи HR-менеджменту.

На наше переконання, HR-менеджмент - це одна 3 головних функцій будьякої сучасної організації, оскільки він може виявитися тим критичним фактором, що визначає успіх або невдачу сучасної організації.

У контексті вищевикладеного нагадаємо, що ст. 1 Закону України “Про державну службу" передбачено функцію 3 управління персоналом державних органів [8]. При цьому чинним законодавством до персоналу державного органу віднесено як державних службовців такого органу, так і інших працівників, що виконують функції з обслуговування [8, ст.ст. 2 (п. 8, ч. 1) та 3 (ч. 4)]. Проте, управління персоналом в державних органах вужче за змістом діяльності, порівняно з управлінням людськими ресурсами. Саме тому, з метою успішної модернізації державної служби доцільно здійснити перехід від роботи 3 управління персоналом до системи управління людськими ресурсам (HRменеджменту).

На сьогодні серед основних відмінностей в концепціях “управління персоналом" та “управлінні людськими ресурсами” (HR-менеджмент), як правило, відзначають такі [21]: HR-менеджмент зорієнтований не на потреби в персоналі в цілому, а на потреби в конкретній робочій силі; управління персоналом розглядає задіяний потенціал організації, в той час як HRменеджмент розглядає персонал з точки зору наявних та нових робочих місць; при управлінні персоналом застосовується пасивна, a при HR-менеджменті активна кадрова політика; при HR-менеджменті створюється інтегрована система кадрового менеджменту, в той час коли управління персоналом передбачає здійснення кадрової політики службою управління персоналом; управління персоналом на відміну від HR-менеджмент не зацікавлене в довгострокових 
інвестиціях у людський капітал; система кадрового менеджменту при управлінні персоналом зорієнтована на колективні цінності, при HR-менеджмент - на індивідуальну роботу з персоналом тощо.

Отже, сучасні реалії дозволяють стверджувати, що сучасний HR виконує не лише сервісні функції, а перетворюється в стратегічного партнера керівництва та має безпосередній вплив на результативність та ефективність державної служби.

Висновки. Таким чином, вітчизняна система державної служби та управління людськими ресурсами об'єктивно потребує радикальної модернізації, насамперед, 3 метою подолання наслідків руйнування колишньої адміністративно-командної системи і старої ідеології “домінування держави над людиною" та забезпечення органів державної влади компетентними, високопрофесійними, ініціативними, патріотично налаштованими управлінськими кадрами. При цьому нові суспільні виклики, пов’язані з пандемією COVID-19 та економічним спадом, а також закріплення курсу на європейську та євроатлантичну інтеграцію у Конституції України в котрий раз підкреслюють доцільність впровадження європейських принципів публічного управління у практику діяльності вітчизняної державної служби у процесі їі модернізації.

Отже, спроможність ефективно діяти у кризових ситуаціях та досягати цілей 3 використанням мінімально можливих ресурсів мають стати новими індикаторами ефективності у сфері державної служби та управління людськими ресурсами в так звану “постковідну епоху". Все це, у свою чергу, вимагає кращої спроможності органів державної влади (насамперед, інституцій “центру уряду" (Секретаріат КМУ, Мінфін, Мін’юст) забезпечувати якість урядових рішень, кращих процедур, більшої цифровізації, розвитку сервісно-орієнтованої культури тощо.

Враховуючи, що успіх модернізації державної служби та управління людськими ресурсами значною мірою залежить від якості HR-менеджменту в державних органах, то питання переосмислення традиційних HR-підходів до роботи $з$ персоналом у державних органах, пошук і закріплення інноваційних HRпрактик (у т.ч. й цифрових), які б враховували потреби державних службовців та створювали умови для їх постійного самовдосконалення, самопізнання й самореалізації в умовах нових викликів постає одним із визначальних пріоритетів реформування державного управління загалом та визначає перспективи наших подальших наукових досліджень.

\section{Jimepamypa:}

1. \#PARoverview - дослідження експертної думки щодо реалізації однієї з найважливіших для України реформ - реформи державного управління (Public Administration Reform). 2021. URL: http://constructive.institute/ projects/paroverv iew?fbclid=IwAR2LI2Bbu7 Thlu6L9jmhc5gyGpY61QGXhJQKfuuMexj6YKxxdGd DkINfZQ (дата звернення: 21.04.2021). 
2. Колодій А.Ф. Парадигми змін і сучасний політичний процес в Україні. ЛРІДУ, 2014 року. URL: https://political-studies.com/wp-content/uploads/2014/03/change-paradigms-modernukraine.ppt (дата звернення: 21.04.2021).

3. Зелінський С.Е. Теоретико-методологічні засади комплексного оцінювання державних службовців та їх службової діяльності в Україні: автореф. дис.. д-ра. наук держ. упр. : 25.00.03. Київ, НАДУ, 2019. 36 с.

4. Рене Декарт. Вікіпедія. URL: https://uk.wikipedia.org/wiki/\%D0\%A0\%D0\%B5\%D0\%BD\% D0\%B5_\%D0\%94\%D0\%B5\%D0\%BA\%D0\%B0\%D1\%80\%D1\%82 (дата звернення: 21.04.2021).

5. Бужимська К.О. Теорія модернізації: виникнення, розвиток, сучасний стан. Вісник ЖДТУ. 2008. №2 (44). С. 216-227.

6. Войтович Р.В. Модернізація державного управління в умовах глобальної інтеграції. Вісник Національної академії державного управління при Президентові України. 2013. № 2. C. 14-23.

7. Про державну службу: Закон України від 10.12 .2015 p. № 889-VIII. URL : https://zakon.rada.gov.ua/laws/show/889-19 (дата звернення: 21.04.2021).

8. Індекс глобальної конкурентоспроможності. URL : edclub.com.ua/.../indeks-globalnoyikonkurentospromozhnosti (дата звернення: 21.04.2021).

9. Індекс сприйняття корупції у світі - 2020. URL: http://cpi.ti-ukraine.org/ (дата звернення: 21.04.2021).

10. Линдюк О.А. Модернізація державної служби в умовах України в умовах глобалізації: дис. ... д-ра. наук держ. упр. : 25.00.03. Київ, 2017. 420 с.

11. Гончарук Н.Т., Прудиус Л.В. Модернізація державної служби та управління людськими ресурсами в Україні. Аспекти публічного управління. 2018. Т. 6, № 1-2. С. 42-51.

12. Офіційний сайт Національного агентства України з питань державної служби. URL : https://nads.gov.ua/ https://nads.gov.ua/ (дата звернення: 21.04.2021).

13. Державна служба статистики України. URL : http://www.ukrstat.gov.ua/ (дата звернення: 21.04.2021)..

14. Деякі питання реформування державного управління України: Розпорядження КМУ від 24 червня 2016 р. N 474-p. URL: https://zakon.rada.gov.ua/laws/show/474-2016-\%D1\%80 (дата звернення: 22.04.2021).

15. Звіт про виконання у 2020 році Стратегії реформування державного управління України. URL: https://www.kmu.gov.ua/storage/app/sites/1/reforms/zvit2021-ukr-web.pdf (дата звернення: 20.04.2021).

16. Придиус Л.В. Управління якістю державної служби України: дис. ...д-ра. наук держ. упр. : 25.00.03. Дніпро, 2018. 517 с.

17. Деякі питання призначення на посади державної служби на період дії карантину, установленого з метою запобігання поширенню на території України гострої респіраторної хвороби COVID-19, спричиненої корона вірусом SARS-CoV-2: Постанова Кабінету Міністрів України від 22.04.2020 p. № 290. URL: https://zakon.rada.gov.ua/laws/show/290-2020 (дата звернення: 20.04.2021).

18. Про внесення змін до деяких законів України щодо відновлення проведення конкурсів на зайняття посад державної служби та інших питань державної служби: Закон України від 23.02.2021 p. № 1285-IX. URL: https://zakon.rada.gov.ua/go/1285-20 (дата звернення: 20.04.2021).

19. Про затвердження Порядку проведення оцінювання результатів службової діяльності державних службовців: Постанова Кабінету Міністрів України № 640 від 23.08.2017. URL :

https://zakon.rada.gov.ua/laws/show/640-2017 (дата звернення: 20.04.2021). 
20. Концепція реформування системи оплати праці державних службовців: Розпорядження КМУ від 27 травня 2020 р. № 622-p. URL: https://zakon.rada.gov.ua/go/622-2020$\%$ D1\%80 (дата звернення: 20.04.2021).

21. Грідін O.B. HR-менеджмент в сучасних організаціях: особливості та перспективи впровадження. Вісник Харківського національного технічного університету сільського господарства імені Петра Василенка. Харків, 2017. Вип. 185. С. 160-172.

\section{References:}

1. \#PARoverview - doslidzhennia ekspertnoi dumky shchodo realizatsii odniiei $\mathrm{z}$ naivazhlyvishykh dlia Ukrainy reform - reformy derzhavnoho upravlinnia (Public Administration Reform) [PARoverview - a study of expert opinion on the implementation of one of the most important reforms for Ukraine - public administration reform (Public Administration Reform)]. constructive.institute. Retrieved from http://constructive.institute/ projects/ paroverview?fbclid=Iw AR2LI2Bbu7Thlu6L9jmhc5g-yGpY61QGXhJQKfuuMexj6YKxxdGdDkINfZQ [in Ukrainian].

2. Kolodii A.F. (2014). Paradyhmy zmin i suchasnyi politychnyi protses $v$ Ukraini [Paradigms of change and the modern political process in Ukraine].Retrieved from https:// political- studies.com/wpcontent/uploads/2014/03/change-paradigms-modern-ukraine.ppt [in Ukrainian].

3. Zelinskyi, S.E. (2019). Teoretyko-metodolohichni zasady kompleksnoho otsiniuvannia derzhavnykh sluzhbovtsiv ta yikh sluzhbovoi diialnosti v Ukraini [Theoretical and methodological principles of comprehensive assessment of civil servants and their service activities in Ukraine]. Extended abstract of Doctor's thesis. Kyiv, NADU [in Ukrainian].

4. Rene Dekart. Vikipediia [Rene Descartes. Wikipedia]. Retrieved from https://uk.wikipedia. org/wiki/\%D0\%A0\%D0\% B5\%D0\%BD\%D0\%B5_\%D0\%94\%D0\%B5\%D0\%BA\%D0\%B0\%D1\% 80\%D1\%82 [in Ukrainian].

5. Buzhymska, K.O. (2008). Teoriia modernizatsii: vynyknennia, rozvytok, suchasnyi stan [Theory of modernization: origin, development, current state]. Visnyk ZhDTU - Bulletin of ZhSTU, 2 (44), 216-227 [in Ukrainian].

6. Voitovych, R.V. (2013). Modernizatsiia derzhavnoho upravlinnia v umovakh hlobalnoi intehratsii [Modernization of public administration in the context of global integration]. Visnyk Natsionalnoi akademii derzhavnoho upravlinnia pry Prezydentovi Ukrainy - Bulletin of the National Academy of Public Administration under the President of Ukraine, 2, 14-23[in Ukrainian].

7. Zakon Ukrainy Pro derzhavnu sluzhbu vid 10 hrud. 2015 roku № 889-19 [Law of Ukraine On Civil Service of December 10. 2015 № 889-19]. Retrieved from http: zakon.rada.gov.ua/go/889-19 [in Ukrainian].

8. Indeks hlobalnoi konkurentospromozhnosti [The Global Competitiveness Index]. Retrieved from edclub.com.ua/.../indeks-globalnoyi-konkurentospromozhnosti [in Ukrainian].

9. Indeks spryiniattia koruptsii u sviti [Corruption Perceptions Index]. Retrieved from http://cpi.ti-ukraine.org/ [in Ukrainian].

10. Lyndiuk, O.A. (2017). Modernizatsiia derzhavnoi sluzhby v umovakh Ukrainy v umovakh hlobalizatsii [Modernization of civil service in the conditions of Ukraine in the conditions of globalization]. Doctor's thesis. Kyiv, NADU [in Ukrainian].

11. Honcharuk, N.T., \& Prudyus, L.V. (2018). Modernizatsiia derzhavnoi sluzhby ta upravlinnia liudskymy resursamy v Ukraini [Modernization of civil service and human resources management in Ukraine]. Aspekty publichnoho upravlinnia - Aspects of public administration, 1-2, 42-51 [in Ukrainian]. 
12. Ofitsiinyi sait Natsionalnoho ahentstva Ukrainy z pytan derzhavnoi sluzhby [Official site of the National Agency of Ukraine for Civil Service Affairs ]. Retrieved from https://nads.gov.ua/ https://nads.gov.ua/ [in Ukrainian].

13. Derzhavna sluzhba statystyky Ukrainy [State Statistics Service of Ukraine]. Retrieved from http://www.ukrstat.gov.ua/ [in Ukrainian].

14. Rozporiadzhennia Kabinetu Ministriv Ukrainy Deiaki pytannia reformuvannia derzhavnoho upravlinnia Ukrainy vid 24.06.2016 r. № 474-r [Order of the Cabinet of Ministers of Ukraine Some issues of public administration reform in Ukraine dated 24.06.2016 № 474-r]. (2016). Retrieved from https://zakon.rada.gov.ua/go/474-2016-\%D1\%80 [in Ukrainian].

15. Звіт про виконання у 2020 році Стратегії реформування державного управління України [Report on the implementation in 2020 of the Public Administration Reform Strategy of Ukraine]. Retrieved from https://www.kmu.gov.ua/storage/app/sites/1/reforms/zvit2021-ukr-web.pdf [in Ukrainian].

16. Prudyus, L.V. (2018). Upravlinnia yakistiu derzhavnoi sluzhby Ukrainy [Quality management of the civil service of Ukraine]. Doctor's thesis. Dnipro, 2018 [in Ukrainian].

17. Postanova Kabinetu Ministriv Ukrainy Deiaki pytannia pryznachennia na posady derzhavnoi sluzhby na period dii karantynu, ustanovlenoho $\mathrm{z}$ metoiu zapobihannia poshyrenniu na terytorii Ukrainy hostroi respiratornoi khvoroby COVID-19, sprychynenoi koronavirusom SARS-CoV-2: vid 22.04.2020 r. № 290 [Resolution of the Cabinet of Ministers of Ukraine Some issues of appointment to civil service positions for the period of quarantine established to prevent the spread of acute respiratory disease COVID-19 caused by coronavirus SARS-CoV-2 in Ukraine: from 22.04.2020 № 290]. (2020, April 22). Retrieved from https://zakon.rada.gov.ua/laws/show/290-2020 [in Ukrainian].

18. Zakon Ukrainy Pro vnesennia zmin do deiakykh zakoniv Ukrainy shchodo vidnovlennia provedennia konkursiv na zainiattia posad derzhavnoi sluzhby ta inshykh pytan derzhavnoi sluzhby: vid 23.02.2021 r. № 1285-IKh [Law of Ukraine On Amendments to Certain Laws of Ukraine Concerning the Resumption of Competitions for Civil Service Positions and Other Civil Service Issues: dated February 23, 2021 № 1285-IX]. (2021, February 23). Retrieved from https://zakon.rada.gov.ua/go/1285-20 [in Ukrainian].

19. Postanova Kabinetu Ministriv Ukrainy Pro zatverdzhennia Poriadku provedennia otsiniuvannia rezultativ sluzhbovoi diialnosti derzhavnykh sluzhbovtsiv: № 640 vid 23.08.2017 [Resolution of the Cabinet of Ministers of Ukraine On approval of the Procedure for evaluating the performance of civil servants: № 640 dated 23.08.2017]. (2017, August 23). Retrieved from https://zakon.rada.gov.ua/laws/show/640-2017 [in Ukrainian].

20. Rozporiadzhennia KMU Kontseptsiia reformuvannia systemy oplaty pratsi derzhavnykh sluzhbovtsiv: vid 27.05.2020 r. № 622-r [Order of the Cabinet of Ministers Concept of reforming the system of remuneration of civil servants: from 27.05.2020 № 622-r]. (2020, May 27). Retrieved from https://zakon.rada.gov.ua/go/622-2020-\%D1\%80 [in Ukrainian].

21. Hridin, O.V. (2017). HR-menedzhment v suchasnykh orhanizatsiiakh: osoblyvosti ta perspektyvy vprovadzhennia [HR-management in modern organizations: features and prospects of implementation]. Visnyk Kharkivskoho natsionalnoho tekhnichnoho universytetu silskoho hospodarstva imeni Petra Vasylenka - Bulletin of the Petro Vasylenko Kharkiv National Technical University of Agriculture,185, 160-172 [in Ukrainian]. 